\title{
Path-Dependence in Chinese Arbitration Law
}

\author{
Fei Lanfang \\ Faculty of Law \\ Jinan University \\ Guangzhou, China \\ fei27@hotmail.com
}

\begin{abstract}
China's early institutional choice of arbitration institutions caused it to be come locked-in and resistant to change. The paper reviews how the path-dependent nature of Chinese legal reform de termines the specific characteristics of the Chinese arbitration system. Moreover, it reveals that outer forces, such as globalization and boom of arbitration market in China may cause a path-breaking effect, which would further determines the future reform direction of Chinese arbitration law.
\end{abstract}

Keywords-arbitration; reform; path-dependent; dual-track; gloalization

\section{INTRODUCTION}

Over the past decades, China has engaged in rebuilding its legal system and creating a modern arbitration law regime. It is acknowledged that Chinese arbitration law incorporates a series of international arbitration norms such as the autonomy of the arbitration clause, the principle of party autonomy, and the principle of flexibility and efficiency of arbitration proceedings [1]. However, despite the convergence towards international norms and practices, the Chinese arbitration legal system has certain unique features [2]. Path-dependent theory could be deployed to explain the divergence of Chinese arbitration law from international norms and its unique characteristics that differs it from other systems [3].

The theory implies "a strong element of institutional inertia" and "once past a certain threshold of development, what exists is likely to persist" [4]. Accordingly, the development of a certain institution seems to be locked-in to a particular path, and all their other choices become dependent on the initial choice [5]. Chinese arbitration law is historically contingent on specific institutional structures established at the beginning of the formal arbitration system during the 1950s. This paper presents how the path-dependent nature of Chinese legal reform led to the preservation of some specific characteristics of Chinese arbitration law. Moreover, the paper analyzes the potential impacts of the outer force on the path of the reform of Chinese arbitration law in the future.

\section{THE PATH-DEPENDENT THEORY}

The concept of path dependent was originally developed by economists to explain the observed lack in tendency when a particular technology becomes accepted as an industry standard or the phenomenon of persistent domination by inferior technologies in competitive markets, despite the availability of superior rivals. Douglass North applied increasing returns-path dependence to explain institutional emergence and change. He explained that incremental change is heavily weighted in favor of policies consistent with the existing institutional framework [6]. Later, the path dependence theory was extended to political and social science to explain the continuity in institutional change and the variability in institutional environments, whether social, political or cultural [7]. Institutions persist over time not only for reasons of legitimacy but also because powerful individuals and groups have vested interests in maintaining the status quo. In broad terms, the path dependence theory implies that "what happened at an earlier point in time will affect the possible outcomes of a sequence of events occurring at a later point in time.” [8]

The path dependent theory has been used by many scholars to explain the development of the Chinese legal system. It is said path dependency and historical institutionalism may resist convergence but maintain variability. The large population, strong military power and isolated economic institutions confer China with greater bargaining power over foreign investors and international organization. Randall Peerenboom argued that although China has not been immune from the forces of globalization, reforms in China have been, and will continue to be, driven primarily by domestic factors because China is a "single party socialist state saddled with a transition economy, an immature legal system, and a historical legacy of more than two millennia in which the subordinate role of law as a means of achieving social order stunted the growth of a culture of legality.” [9] Scott Wilson studied the involvement of Japanese and US investors and lawyers in Chinese International Economic and Trade Arbitration Commission (CIETAC) arbitration and their attitude and use of relation. He found that the combination of relation and formal legal institutional change constituted a model of path-dependent institutional change of Chinese arbitration [10]. Based on the previous studies, this paper will focus on how the path of Chinese arbitration law is shaped and what kind of forces will determine the future of Chinese arbitration law.

\section{Path-DePendent ARBitration LAW IN China}

Although the PRC was officially established in 1949, the modern legal infrastructure was not established until the end of the 1970s. Prior to the 1970s, the legal system in China followed the model and ideals of Soviet Union and Japan, while the system after the 1970s was more influenced by European and North American legal norms and ideology. The culture and political pattern have determined that Chinese legal reform is greatly constrained by domestic factors. As part of 
the Chinese legal system, the development of Chinese arbitration law also indicates a path-dependent nature.

\section{A. The Critical Juncture of the Establishment of Chinese Arbitration Institutions}

The concept of "critical juncture" is an essential building block of path-dependent theory. When we trace the history of the Chinese arbitration system, the establishment of the Foreign Trade Arbitration Commission (FTAC) of the China Council for the Promotion of International Trade (CCPIT) in 1953 was the first critical juncture in the development of Chinese arbitration institutions, rules and practices, as it was the starting point of the entire institutional framework. Specifically, the path dependence of Chinese arbitration indicated several special characteristics including: (1) Government-guided administered arbitration; (2) Unbalanced development of foreign-related arbitration and domestic arbitration; (3) Institutional arbitration. In conclusion, the central government chose a quasi-administrative institutional foreign-related arbitration that determined the future path of the development of the arbitration institution in China.

First, in many other jurisdictions, arbitration grew out of the need for commercial trade. For instance, in England, the merchant gilds and craft gilds were organization for the purpose of mutual arbitration. What appears to be unique about the approach in China is the extent of governmental control and guidance. In other jurisdictions, arbitration laws came into existence after the initial development of arbitration. However, in China, arbitration laws were created as part of the process of developing an arbitration market. In fact, Chinese arbitration law did not come into existence in the face of a pre-existing and well-developed arbitration market. The development of arbitration is totally reliant on central government. Indeed, the State council acted as an active controller for guiding the process of the establishment of the FTAC. Without the decision made by the central government, it was unfeasible to have an arbitration institution in 1953.

The FTAC was a commission under the CCPIT, which was a quasi-administrative agency of the central government. The CCPIT was established for the avowed purpose of providing a nongovernmental organization for the promotion of foreign trade, committed by the Chinese government in 1952 at the Moscow International Economic Conference. It was a social association of prominent individuals interested in foreign trade that had no relation to the government. Nevertheless, by its nature, its personnel and finances were determined by the central government. As a practical matter, it was treated as a quasi-official organ that performed certain public functions under the guidance and control of the government. The FTAC, therefore, assumed a quasi-administrative nature. It was financially supported by the central government.

The rank of the FTAC is high in the administrative hierarchical system in China. It was established by the State Council directly. As outlined previously, the Provisional Rules specified that the award rendered by the Commission is final and is not subject to judicial review by the court. This rule was consistent with the tendency of modern arbitration law to prevent courts from interfering with arbitration. However, the rules essentially stemmed from the intention that the FTAC held a high administrative rank; thus, it could not be supervised by the courts of China, which at that time were inferior in the overall state institutional infrastructure.

Second, the intention to establish Chinese arbitration institution was initiated by the concern for protecting state firms in foreign trade. A typical practical example of such concern was cited as follows: In 1953, the China National Animal By-Products Corporation made a contract for 29 tons of wool by cable with British Seedcake \& Rapeseed Company. After making the deal, the British party sent a letter of confirmation to the Chinese party for review and signature. The letter of confirmation stated that if there was any dispute arising from this transaction, it should be arbitrated by the British Brand Forward Association. The Chinese party was worried about this arbitral clause, but unfortunately there was no arbitration institution that handled foreign affairs in China at that time. Therefore, the purpose of the establishment of the FTAC was to protect Chinese State-owned enterprises from unfair treatment by arbitrators and arbitration tribunals of western countries. It aimed to settle disputes arising from "contracts and transactions in foreign trade, particularly disputes between foreign firms, companies or other economic organizations on the other."

There was neither a policy for developing domestic arbitration nor was there any concern regarding domestic markets at that time. Although China had de veloped a domestic administrative arbitration system in the early 1950s, the dispute resolution institution was virtually established inside economic commissions at various levels; it was mandatory for parties to submit their dispute to those arbitration institutions. They were an administrative dispute institution rather than the modern-day arbitration body. Domestic arbitration could be conducted automatically by administrative departments without an arbitration agreement between the parties. The domestic arbitral awards could be appealed to the courts. Most importantly, the domestic arbitral institutions were attached to the administrative organ of the government. Simply put, early administrative arbitration seems to oppose the very spirit of modern arbitration, and one may not consider it arbitration in the true sense.

Third, modern arbitration originated from ad hoc arbitration. Few countries denied the effectiveness of ad hoc arbitration. However, ad hoc arbitration had never existed in China. At the early stage of arbitration in China, the government had not considered ad hoc arbitration. The FTAC was an arbitration body with strong administrative powers. Its name "commission" somehow implied the high administrative control of arbitrators and arbitral proceedings of the commission board. The reason for ignoring ad hoc arbitration was attributable to the fact that the development of arbitration in China was not controlled by the Chinese market but rather by the central government. The Chinese government had a tradition of trusting organization.

Although Chinese law had never expressly forbidden ad hoc arbitration, relevant provisions always mentioned an arbitration institution, ignoring ad hoc arbitration completely. The statutes always stated that, if a dispute could not be settled 
by consultation, it could be arbitrated by an arbitration institution in the PRC. Therefore, only an arbitration institution could conduct arbitration cases in China, whereas a single arbitrator could not solely handle a case.

\section{B. The Introduction of Chinese Arbitration Law: Lock-In Features}

According to the path-dependent theory, the critical juncture secures the future development of an institution. The critical juncture of the choice of the arbitration-developing path in 1953 significantly shaped current rules and practices of arbitration institutions. However, the promulgation of the $\mathrm{AL}$ in 1994 virtually provided a new legal framework for Chinese arbitration. It is viewed as a milestone in Chinese arbitration history and in the development of the Chinese legal system. It provided a regulatory framework for the development of arbitration in China. The AL is considered a piece of modern arbitration legislation. It outlined modern arbitration principles including party autonomy, independent arbitration and the finality of arbitral awards. It confirmed the legal status of foreign-related arbitration and opened the door to establishing a modern domestic arbitration system in China. After the implementation of the $\mathrm{AL}$, a number of domestic arbitration commissions were established all over China. It can be concluded that at the regulatory level, the Chinese AL generally converged with suitable and modern arbitration rules and practice. However, when we look into the details of the institutions, rules and practices of the Chinese administrative system, the three features of the path determined in the first critical juncture still remain.

Article 8 of the AL 1994 provides that arbitration shall be carried out independently and shall be free from interference of administrative organs, social organization or individuals. However, the reality is not exactly consistent with the requirement of the law. The nature of the FATC had a profound historical influence on the development of modern arbitration infrastructure in China after the Culture Revolution. In February 1980, the State Council issued "Notice Concerning the Conversion of the FTA Commission into the Foreign Economic and Trade Arbitration Commission (FETAC)", which re-established the FTAC but renamed it as FETAC. In June 1988, the FETAC amended its name to the CIETAC. However, the CIETAC was not separated from the Legal Department of the CCPIT until 2002 when it was registered as an independent legal institution. Even if the CIETAC was legally an independent arbitration body, it naturally was a public institution. It was not totally independent and had to consider the government benefit.

The administrative developing path also determined the establishment of other arbitration commissions. For a long time, the CMAC was an institution inside the CCPIT. The CIETAC South China was under the leadership of the Shenzhen Municipal Government, while the CIETAC Shanghai was set up and administered by the Shanghai Council for the Promotion of International Trade with the approval of the Shanghai Municipal Government. The Circular was issued by the State Council in 1995 for the implementation of the Arbitration Law, which required the reorganization of local arbitration institutions affiliated with administrative authorities.
According to the $\mathrm{AL}$, domestic arbitration commissions may be set up directly under the provincial governments of provinces and autonomous regions and are organized by the local chamber of Commerce at the provisional level. They may also be established in other municipalities with districts. The AL expressly provides that the domestic arbitration commissions must be independent from administrative authorities. There must be no subordinate relationship between domestic arbitral institutions and administrative authorities. However, the legislative requirement of an independent domestic arbitral commission by local administrative authorities is not realistically effective.

The ignorance of domestic arbitration resulted from the development of a domestic arbitration system that lagged behind the development of foreign-related arbitration. On the legislative level, the unbalanced development of foreign-related and domestic arbitration commissions caused the $\mathrm{AL}$ to provide two legal regimes: a foreign-related arbitration legal regime and domestic arbitration legal regime. Specifically, China has a bifurcated arbitration system-domestic and foreign-related or international. Domestic cases include not only two Chinese parties but also parties with foreign investors. "Foreign-related" indicates at least one foreign party, or a foreign subject matter, is involved in the arbitration. The PRC Arbitration Law governs both domestic and international arbitrations. The provisions of Chapter 7 of the PRC Arbitration Law specifically apply to international arbitrations. The other provisions of the PRC Arbitration Law apply to both domestic and foreign-related arbitrations.

In addition, the Chinese Arbitration Act 1994 provided a way to ignore ad hoc arbitration. Article 16 of the PRC Arbitration Law provides that the arbitration agreement must designate "an arbitration commission" selected by the parties. Article 18 further stipulates that if the arbitration agreement does not reference an arbitration commission, absent the parties reaching a supplemental agreement, the arbitration agreement shall be invalid. Accordingly, it is impossible to conduct ad hoc arbitration in the PRC. As a result, lots of arbitration agreements without arbitration clauses chosen were deemed invalid.

\section{Potential Impacts on the Distinct Features of Chinese Arbitration Law}

The introduction of new ideas and the change in the institutional infrastructure can break the lock-in effect of path dependence and can spur institutional reform. Just as Wilson Scott put it:

"Globalization can compel and catalyze institutional change through the following four processes: enhancing information flows and creating new feedback mechanisms; disrupting coalitions in support of existing institutions at the micro level through the entry of MNCs, bringing macro-level pressure for institutional change from integration with international economic and treaty organizations; and fostering a general structure of competition that heightens the importance of reading feedback correctly, both at the macro and micro levels." 
An early path may be diverted by the impaction of outer and inner forces. The previously mentioned features of Chinese arbitration law are faced with pressures from various interest groups. Those forces may impact the features of the previous path and cause path-creating or path-breaking effects.

First, foreign countries have put diplomatic pressure on the enforcement of arbitration law in China. China became a member of the New York Convention in 1987. By becoming a member of the New York Convention, China was introduced to the modern international arbitration norm. The AL 1994 realized a lot from the provisions of the NYC with respect to enforcement of foreign-related arbitral awards. However, there have been many enforcement problems in China. A typical example is the Revpower case, in which the foreign award could not be enforced without diplomatic pressure from the U.S. government and foreign business fraternities [11]. The outside pressure finally caused a path-breaking of Chinese arbitration law by establishing a reporting mechanism, which, to a great extent, secured the enforcement of international arbitral awards.

Second, foreign investors preferred to resolve disputes through arbitration, which require a great diversity of expertise including professional international arbitration lawyers and arbitrators. Although foreign lawyers could not provide opinions on Chinese legal issues in arbitration proceedings, they handled matters by cooperating with their Chinese correspondents. This professional international group brought international norms to the Chinese arbitration market; their criticism on the function of arbitration in China could act as a force to improve the system. For instance, Jerome A. Cohen, the famous Chinese law scholar and arbitrator of the CIETAC, criticised the commission for corruption citing specific instances in 2004. He said he would advise clients to stay away from the commission. Soon after that, CIETAC adopted some reforms based on Cohen's suggestions; that was a typical example of the path-breaking effect caused by outer pressure [12].

Third, the restriction of ad hoc arbitration and foreign arbitration in China is faced with the challenge of international arbitration institutions. Notably, the ICC opened a branch Secretariat office in Hong Kong, which specifically handles Asia-related arbitration cases. It advocates that international arbitration bodies try to fight for the arbitration market of China. The new branch was established principally for the large market of Mainland China. International arbitration bodies have called on China to relax the legal restrictions on the arbitration market and the rigid requirements of the chosen arbitration Commission in an effective arbitration agreement. Robert Briner, former chairman of the ICC Court, stated that a narrow interpretation of relevant provisions of the AL would run contrary to China's own interest.

Fourth, growth of the arbitration market and arbitration bodies established accordingly has impacted the current arbitration legal system. The opening of the domestic arbitration market caused a change in the dual-track arbitration legal regime in terms of different jurisdiction between so-called foreign-related arbitration commissions and domestic arbitration commission. In 1998, the CIETAC's jurisdiction was extended to cover disputes involving FIEs. In 2000, foreign-related and domestic arbitration commissions could accept international and domestic cases. This was viewed as a change to "answer domestic demand for superior domestic arbitration service" and "was also indicative of the need for CIETAC to improve the competitiveness and place itself on an equal footing with Chinese domestic arbitral commissions." Furthermore, these arbitration commissions also advocated that the dual-track system should be made uniform. In judicial practice, the different standards and requirements have created some chaos and inconsistencies.

\section{CONCLUSION}

Applying the path-dependent theory to the evolution of Chinese arbitration law led to striking insights. It revealed that China's early institutional choice of arbitration caused it to become locked-in and resistant to change. Based on the previous analysis, from the perspective of the theory of pathdependent and institutional change, the arbitration legal system in one country may differ that of other countries because of the path-dependent nature of the institutional development. The path-dependent nature of Chinese legal reform determines the specific characteristics of the Chinese arbitration system. Positive feedback and self-reinforcing mechanisms would reinforce the movement along one path, while changes in initial conditions, such as initial policy considerations and institutional foundations, and negative feedback may cause a path-breaking effect.

\section{REFERENCES}

[1] Jinzhou TAO and Glarisse Von Wunschheim, "Article 16 and 18 of the PRC A rbitration Law: The Great Wall of China for Foreign Arbitration Institutions”, Arbitration International, Vol. 23, pp. 309-310. 2007.

[2] David J.Howell, “An Overn of Arbitration Practice in Asia”, INT'L ARB. L.REV. Vol. 4, pp. 143, 2001.

[3] Katherine Lynch, The Forces of Economic Globalization: Challenges to the Regime of International Arbitration, The Hague: Kluwer Law International, 2003.

[4] Stan Liebowitz and Stephen E. Margolis, "Policy and Path Dependence: From QW ERTY to Windows 95,” Regulation, Vol. 18, No. 3, pp. 134137, 1995.

[5] Paul David. "Clio and the Economics of QWERTY", American Economic Review, Vol.1 , pp. 332. 1995.

[6] Douglass C. North, Institutions, Institutional Change and Economic Performance, Cambridge:Cambridge University Press, 1991.

[7] Oliver Wendell Holmes, The Path of the Law, in Collected Legal Papers ,1920, pp.167-189.

[8] Scott Wilson,Remade in China: Foreign Investors and Institutional Change in China, New York,Oxford University Press, 2009, pp.5-15.

[9] Randall Peerenboom, "Globalization, Path Dependency and the Limits of Law: Administrative Law Reform and Rule of Law in the People's Republic of China”, Berkeley J. Int'l L. Vol. 19, pp.161, 2001.

[10] Scott Wilson: Law Guanxi: MNCs, state actors, and legal reform in China, Journal of Contemporary China, Vol.17, pp.25-51, 2008.

[11] Alberto Mora,’'The Revpower Dispute: China's Breach of the New York Convention?”, in China Law \& Pracitce, (ed.),Dispute Resolution in the PRC: A Practical Guide to Litigation and Arbitraiton in China, Hong Kong: China Law \& Prctice, pp.151, 1995.

[12] Fan Kun, "Prospects of Foreign Arbitration Institutions Admin istering Arbitration in China”, Journal of International Arbitration, Vol 28(4), pp.343-353,2001. 